KEMAS 10 (2) (2015) 129-136
Jurnal Kesehatan Masyarakat

\title{
RISK FACTORS OF MALARIA INCIDENCE WITH SPASIALS APPROACHING
}

\author{
Masrizal Dt.Mangguang ${ }^{\bowtie}$ \\ Public Health Faculty, University of Andalas
}

\section{Info Artikel}

Sejarah Artikel:

Diterima 28 September 2014

Disetujui 28 November 2014

Dipublikasikan Januari 2015

Keywords:

Mixed garden;

Mosquito nets;

Marshes;

Repellent.

\begin{abstract}
Malaria caused by sporozoa of plasmodiumthat infected to human by female Anopheles mosquitos with periodical feverish phenomena, anaemia, limpha's amplification, and another phenomena. In Padang city, API on 2011 as big as 0,4, it's greater than 2010 with API 0,22. The purpose of this research was to know risk factors and distribution of malaria at Padang City. This research has been done in 2012 used case control study with 58 samples, consisting of 29 cases and 29 controls. Data collecting with questionnaire. Analysis univariat, bivariat, and multivariate, spatial analysis by using Epi Info 7 and Arc View GIS. The results of the study were most of cases living around marshes and garden, had outdoor activity at night, and didn't use nets and repellent. Bivariate analysis that becomes risk factor of malaria were using nets $p=0,025(O R=4,480, C I=1,339-14,991)$, using repellent $p=0,018(O R=4,222, C I=1,409-12,657)$, had outdoor activity at night $p=0,029$ $(O R=4,107, C I=1,292-13,057)$, and living around garden $p=0,004(O R=5,971, C I=$ 1,901-18,754). The results of analysis spatial showed that malaria incidence found in most of districts and around the river. The conclusion, the most dominant risk factors were nets used, repellent used, and living around garden.
\end{abstract}

\section{FAKTOR RISIKO INSIDENSI MALARIA DENGAN PENDEKATAN SPASIAL}

\begin{abstract}
Abstrak
Malaria masih menjadi masalah kesehatan masyarakat Indonesia. API Kota Padang pada tahun 2011 sebesar 0,4, meningkat dibanding tahun sebelumnya yang sebesar 0,22 . Tujuan dari penelitian ini adalah mengetahui faktor risiko kejadian serta distribusi malaria di Kota Padang. Penelitian dilakukan pada tahun 2012 dengan desain penelitian case control study pada 58 orang sampel, terdiri dari 29 kasus dan 29 kontrol. Variabel penelitian adalah kebiasaan pemakaian kelambu, penggunaan obat anti nyamuk, kebiasaan keluar rumah malam hari, keberadaan rawa-rawa, dan keberadaan kebun campur. Pengumpulan data melalui kuesioner. Analisis univariat, bivariat, multivariat, dan analisis spasial dengan Software Epi Info 7 dan Arc View GIS. Hasil penelitian yaitu kelompok kasus lebih banyak tinggal di sekitar rawa-rawa dan kebun, kebiasaan keluar rumah malam hari, serta tidak menggunakan kelambu dan anti nyamuk. Analisis bivariat menunjukkan faktor risiko malaria adalah pemakaian kelambu $\mathrm{p}=0,025(\mathrm{OR}=4,480, \mathrm{CI}=1,339-14,991)$, penggunaan anti nyamuk $\mathrm{p}=$ $0,018(\mathrm{OR}=4,222, \mathrm{CI}=1,409-12,657)$, kebiasaan keluar rumah pada malam hari $\mathrm{p}=0,029(\mathrm{OR}=$ 4,107, CI = 1,292-13,057), dan keberadaan kebun $\mathrm{p}=0,004(\mathrm{OR}=5,971, \mathrm{CI}=1,901-18,754)$. Hasil analisis spasial menunjukkan distribusi kejadian malaria hampir di seluruh kecamatan dan sekitar aliran sungai. Simpulan penelitian yaitu ada hubungan yang bermakna pada kebiasaan pemakaian kelambu, penggunaan anti nyamuk, keluar rumah pada malam hari, dan keberadaan kebun campur terhadap kejadian malaria. Faktor risiko dominan yaitu pemakaian kelambu, penggunaan obat anti nyamuk, dan keberadaan kebun campur.
\end{abstract}

(c) 2015 Universitas Negeri Semarang 


\section{Introductions}

Malaria is an communicable disease, is strongly influenced by the interaction between the agent, hosts, and environment. Host factors influenced by age, sex, heredity, state of physiology, immunity, previous illness, and personal hygiene. Factors agent that is the cause of the disease can be life elements such as viruses, bacteria, fungi, protozoa, fungi, and worms are also a die elements such as pharmaceuticals, pesticides, chemicals and radioactive rays. Environmental factors are extrinsic factors that support the occurrence of the disease, can be either physical environment (geographical and seasonal), temperature, rainfall, humidity, environmental, biological (flora and fauna) and socio-cultural environment (Babba, 2008. Kritsiriwuthin K, 2011).

Malaria is still a health problem in the world. Malaria can cause death, especially in high-risk groups, namely infants, young children, pregnant women. Each year, as many as 655,000 people died from malaria, mostly in Africa (596,000 people, $80.93 \%$ ), while in Asia as many as 38,000 deaths ( $6 \%$ of total world mortality). Meanwhile, at least 3.3 billion people at risk of malaria, with 216 million of them positive malaria (Ernst KC, 2009 ; Handayani, 2008)

Department of Health states that people living in malaria endemic areas in 2008 almost in half of the territory of Indonesia with $49.7 \%$ of the population or 107.785 .000 and 217.328.000 Indonesia's population live in areas at risk of becoming the spread of malaria. As for the number of malaria patients in 2011 was 256592 people, of which 388 people died. This amount is lower than the number of deaths in 2010 was 432 people. The decline also occurred in Annual Parasite Incidence (API) in 2011 was 1.75 / 1,000 population, compared jik of 4.3 / 1000 population in 2005.

In the Annual Report of the Provincial Health Office of West Sumatra in 2010, the number of malaria cases in the province of West Sumatra in 2010 as many as 1109 cases with API (Annual Incidence Paracite) of 0.22 and then increased during the year 2011 with the API of 0.43 . While the city of Padang is the capital of the province became the third lar- gest city found cases of malaria after Sijunjung district and Mentawai Islands during 2010, as many as 187 cases with AMI (Annual Malaria Incidence) of 2.31. Then during the year 2011 malaria cases increased by 340 people returned to the API of 0.4. Padang city also includes several districts / cities with the highest incidence of malaria in West Sumatra during the period 2010-2011 (Masrizal, 2010).

According Mardihusodo (2007), explained that the application of GIS to the study of the dynamics of the spread of mosquito monitoring as a database, it is necessary quantitative data concerning the epidemiology of malaria cases, the clinical symptoms of patients with positive parasitemia, which includes incidence and prevalence by location (village, sub-district, district and so on), vector, malaria parasites, and ecological environment, such as the elements of geographical, climatological, biological, demographic, and socio-economic (Masrizal, 2011; Mardiana, 2007).

Geographic Information Systems are useful in mapping malaria based on geographic conditions, making it easier to analyze the spread of malaria cases by looking at the state of the environment and consider the risk factors that exist and then be taken into consideration or suggestion in determining malaria control policies effectively and efficiently (Masrizal, 2010; Ernst KC, 2009; Friaraiyatini, 2006).

In various researches that have been done before, mapping and spatial analysis of malaria cases has not been done in the Padang city. The output of this research is going to be known distribution of malaria cases and and then associated with risk factors for the incidence of malaria by looking from the geographical point of view, such as the state of the region and the environment. Then it should be done as an alternative in view of the development trend of the spread of malaria.

The problem of this study is "What are the risk factors affecting the incidence of malaria and spreading in the city of Padang in 2012 ?"

General purpose of this study is to determine the risk factors that influence the occurrence of malaria and spatial analysis of malaria incidence in the Padang city in 2012.

Improve the ability of researchers to analyze problems, add insight and enhance the 
skills of researchers on spatial analysis of malaria incidence. This research can also be used as a reference for other researchers in conducting further research.

As the literature and contributed scientific insights in the development of Public Health Sciences, specialization in particular on the analysis of spatial epidemiology and risk factors for malaria.

For information relating to the distribution of cases of malaria incidence and risk factors that can be used as consideration for the West Sumatra Provincial Health Office and the City Health Office of Padang in malaria control programs.

As the information for people to understand the spread of malaria and knowing the risk factors of the disease so as to improve the early warning community in malaria prevention.

\section{Methods}

The research methods used is observational analytic quantitative approach with study design of case control study, which studied the relationship between exposure and disease by comparing the case group with the control group based on the exposure.

Population cases, entire positive malaria patients recorded in the data registers Padang City Health Department during the month of January to June 2012. Control population, all those who declared free of malaria who resides in the city of Padang during the months of January to June 2012.

The sample is part of a population that is considered to represent the characteristics of the population to be studied. In this study, the sample consisted of cases and controls.

Sample size, the number of samples required in this study can be calculated with the formula.

The ratio between the case and control samples was 1: 1 with matching age and gender, so that the overall number of sample cases is 32 $+32=64$ controls

Sampling technique in this study carried out by simple random sampling is random sampling and simple with lottery techniques. The samples made after note the proportion of malaria cases per district.

Data analysis, univariate analysis was conducted to determine the frequency distribution of each variable, namsely the use of mosquito nets, the use of anti-mosquito drugs, a habit out of the house at night, and the presence of swamps and mixed garden. Then the data is presented in the form of tables, graphs, and diagrams to make it more interesting and easier to understand.

Bivariate analysis was conducted to determine the relationship between each independent variable (is the use of mosquito nets, the use of anti-mosquito, habits out of the house at night, and the presence of swamps and mixed garden) with the dependent variable (incidence of malaria). To see the relationship between these variables, chi-square test was used in SPSS software with the degree of confidence (CI) $95 \%$ and $\alpha=0.05$. The relationship is said significant when $\mathrm{p}<0.05$ and see the value of odds ratios (OR) to estimate the risk level of each variable studied.

Multivariate analyzes were performed to examine the relationship of independent variables with the dependent variable, and independent variables are most closely related to variable dependent. Multivariate analysis performed by entering all independent variables (use of mosquito nets, the use of anti-mosquito drugs, a habit out of the house at night, and the presence of swamps and mixed garden) which has a value of $p<0.25$. The test used is logistic regression method Backward L / R in SPSS software to determine which variables are most associated with the incidence of malaria.

Spatial analysis using the software Epi Info 7 for mapping the coordinates of the location of residence of malaria that have been taken with a GPS and see the mapping in terms of areal distribution of malaria incidence associated with the presence of swamps and mixed garden located in the area. ArcView 3.3 software is used to display the results overlay mapping the incidence of malaria in the city of Padang.

\section{Results and Discussion}

Based on the above table 1 can be seen that respondents who did not use mosquito nets when sleeping at night more case group 
Tabel 1. Correlations the Use of Mosquito Nets, Use of Anti Mosquito (repellent), Habit Out of the House at Night , Swamps, Mix Garden with Incidence of Malaria in Padang City in 2012

\begin{tabular}{|c|c|c|c|c|c|c|c|c|}
\hline \multirow{3}{*}{ Variable } & \multicolumn{4}{|c|}{ Malaria } & \multirow{3}{*}{ Total } & \multirow{3}{*}{$\mathrm{p}$} & \multirow{3}{*}{ OR } & \multirow{3}{*}{$\begin{array}{l}\text { CI } \\
(95 \%)\end{array}$} \\
\hline & \multicolumn{2}{|c|}{ Case } & \multicolumn{2}{|c|}{ Control } & & & & \\
\hline & $\mathrm{f}$ & $\%$ & $\mathrm{f}$ & $\%$ & & & & \\
\hline \multicolumn{9}{|l|}{ Use of mosquito nets } \\
\hline Do not use ( at risk) & 24 & 82.8 & 15 & 51.7 & 39 & 0.025 & 4.480 & $1.339-14.991$ \\
\hline Use (not at risk) & 5 & 17.2 & 14 & 48.3 & 19 & & & \\
\hline \multicolumn{9}{|c|}{ Use of anti mosquito (repellent) } \\
\hline Do not use ( at risk) & 20 & 69 & 10 & 34.5 & 30 & 0.018 & 4.222 & $1.409-12.657$ \\
\hline Use (not at risk) & 9 & 31 & 19 & 65.5 & 28 & & & \\
\hline \multicolumn{9}{|c|}{ Habit out of the house at night } \\
\hline Ussual (Risk) & 15 & 51.7 & 6 & 20.7 & 21 & 0.029 & 4.107 & $1.292-13.057$ \\
\hline Unussual (not at risk) & 14 & 48.3 & 23 & 79.3 & 37 & & & \\
\hline \multicolumn{9}{|l|}{ Swamps } \\
\hline There are (at risk) & 17 & 58.6 & 10 & 34,5 & 27 & 0.114 & 2.692 & $0.929-7.801$ \\
\hline None (not at risk) & 12 & 41.4 & 19 & 65,5 & 31 & & & \\
\hline \multicolumn{9}{|l|}{ Mix Garden } \\
\hline Exist (At Risk) & 19 & 65.5 & 7 & 24,1 & 26 & 0.004 & 5.971 & $1.901-18.754$ \\
\hline None (not at risk) & 10 & 34.5 & 22 & 75,9 & 32 & & & \\
\hline Constant & 29 & 100.0 & 29 & 100.0 & 58 & & & \\
\hline
\end{tabular}

Source : primary data

(82.8\%) compared with the control group (51.7)\%. The results of the statistical test chi square $\mathrm{p}$ value $=0.025$ which means that there is a significant correlation between habitual using mosquito net with incidence of malaria. Value Odds Ratio $(\mathrm{OR})=4.480$ states that respondents who do not usually wear mosquito nets when sleeping at night 4.480 times greater risk affected by malaria.

Respondents who did not use mosquito nets while sleeping night had potential contact with mosquitoes bite more often, and not a barrier to approaching mosquitoes when sleeping. In principle, mosquito nets serve as the dividing space between mosquitoes with a sleeping person, let alone a night time mosquito foraging activity. Mosquito nets are used also must be used, no holes that can be a place out of the mosquito so that we avoid from mosquito bite.

Based on the above table it can be seen that the respondents were not using mosquito repellent when nighttime sleep is higher in the case group is as much as $69 \%$ compared with the control group with $34.5 \%$. The results of the statistical test chi square $\mathrm{p}$ value $=0.018$ which means that there is a significant correlation between habitual use of anti mosquito with malaria incidence. Value Odds Ratio $(\mathrm{OR})=$ 4.222 states that the respondents who are not accustomed to using mosquito anti when going to sleep at night has a factor 4,222 times greater risk affected by malaria.

Anti mosquitoes there are used to kill mosquitoes, repel mosquitoes from inside the room, and some are just for perch and prevent mosquito bites a human body part. The use of anti-mosquito can actually be adapted to existing circumstances and conditions, such as using mosquito repellent topical (lotion) to avoid shortness of breath and allergies due to anti-mosquito and / or use of anti-mosquito electric to make it more practical.

Based on the above table it can be seen that respondents who usually leave the house in groups of more cases (51.7\%) compared with the control group (20.7\%). The results of the statistical test chi square $\mathrm{p}$ value $=0.029$ which means that there is a significant correlation between the habit of going out at night with the incidence of malaria. Value Odds Ratio (OR) = 4.107 states that respondents who usually leave the house at night to have a factor 4,107 times 
greater risk affected by malaria.

The habit of going out at night either to work or watch or sit and drink coffee in the shop contacts at risk for mosquito bites. Anophe les mosquitoes are usually out of the nest and actively feed at night to early morning (eksofagik), because the mosquitoes need blood to fulfill its gonotropic. This habit becomes more risky if the person does not use a night out outfit covering the whole body or use a mosquito repellent before going out of the house.

Percentage out of the house at night were higher in is case group were $51.7 \%$, higher than the control group (20.7\%) showed a habit or a number of activities carried out at night so that the risk of coming into contact with mosquitoes. Based on interviews, the activities carried out outside the house while the other is working, sit and drink coffee in the shop, and a small portion to patrol.

Based on the table it can be seen that respondents who live in the marshes around much more in the case group with $58.6 \% \mathrm{com}$ pared to the control group (34.5\%). The results of the statistical test chi square $\mathrm{p}$ value $=0.114$, $\mathrm{p}$-value $\geq 0.05$, which means that there is no significant relationship between the presence of a swamp with malaria incidence.

The existence of the marsh is one of the environmental factors that potentially provide breeding sites (breeding place) for Anopheles mosquitoes. Soil conditions and plant overgrown with weeds and submerged into a preferred place to rest or breed mosquitoes. Freshwater ecosystem and brackish water habitats and offer suitable breeding ground for several species of Anopheles, such Anopheles subpictus and Anopheles sundaicus.

The results of the bivariate analysis that shows the value of $p=0.114$, greater than 0.05 . That means that the existence of a swamp is not associated with the incidence of malaria in the city of Padang. That is because many of the respondents who live in the area that there is no bog as many as 31 people from 58 respondents, or $53.4 \%$. Based on the well known observation that in some places, swamps located somewhat away from the settlement. Another possibility is the portion of the marshes have salinity> $40 \%$ whereas the Anopheles mosquito grows optimally at salt levels ranged between $12-18 \%$.
Based on the above table it can be seen that respondents who reside in the surrounding gardens more mixed in the case group compared with $65.5 \%$ with the control group were $24.1 \%$. The results of the statistical test chi square $\mathrm{p}$ value $=0.004$ which means that there is a significant association between the presence of mixed garden with malaria incidence. Value Odds Ratio $(\mathrm{OR})=5.971$ states that respondents who lived to be around mixed garden has a risk factor of 5.971 times more likely to be exposed to malaria.

The existence of mixed garden as environmental factors that support in providing habitats for Anopheles mosquitoes was instrumental in the spread of mosquitoes and malaria transmission. Conditions mixed garden overgrown with various plants that can block the entry of sunlight, causing the ground beneath it becomes moist. Linkages mixed garden with the incidence of malaria is that the availability of dense vegetation cover and vary in mixed garden, which can make the garden a place of rest mixed mosquito.

Vegetation with high density is the most preferred place to rest after the Anopheles mosquito sucking blood while waiting for the development of the egg or break before looking for blood again. That's what makes mosquitoes at home and make the garden as a place of mixed breeding (breeding place).

Multivariate analysis was conducted to determine how much influence together a set

Table 2. Dominant Factors Affecting Malaria Incidence In Padang City in 2012

\begin{tabular}{lllll}
\hline Variable & $\mathrm{B}$ & $\begin{array}{l}\mathrm{p} \text {-value } \\
(\mathrm{sig})\end{array}$ & $\mathrm{OR}$ & $\begin{array}{l}\mathrm{CI} \\
(95 \%)\end{array}$ \\
\hline $\begin{array}{l}\text { Using of } \\
\text { mosquito net }\end{array}$ & 1.278 & 0.025 & 4.480 & $\begin{array}{l}1.339- \\
14.991\end{array}$ \\
$\begin{array}{l}\text { Using anti- } \\
\text { mosquito }\end{array}$ & 1.765 & 0.018 & 4.222 & $1.409-$ \\
$\begin{array}{l}\text { (repellent) } \\
\begin{array}{l}\text { Habit out of } \\
\text { the house at }\end{array}\end{array}$ & 1.444 & 0.029 & 4.107 & $1.292-$ \\
night & & & & 13.057 \\
$\begin{array}{l}\text { The existence } \\
\text { of swamps }\end{array}$ & 1.187 & 0.114 & 2.692 & $0.929-$ \\
$\begin{array}{l}\text { The existen- } \\
\text { ce of mix }\end{array}$ & 2.165 & 0.004 & 5.971 & $1.901-$ \\
garden & & & & 18.754 \\
\hline
\end{tabular}

Source : primary data 
Tabel 3. Result of Analysis with Logistic Regression

\begin{tabular}{lllll}
\hline Variable & $\mathrm{B}$ & $\mathrm{p}$-value & Exp.B & $\begin{array}{l}\mathrm{CI} \\
(95 \%)\end{array}$ \\
\hline $\begin{array}{l}\text { Using of mos- } \\
\text { quito net }\end{array}$ & 1.847 & 0.025 & 6.343 & $\begin{array}{l}1.329- \\
30.281\end{array}$ \\
$\begin{array}{l}\text { Using } \\
\text { anti-mosquito } \\
\text { (Repellent) }\end{array}$ & 1.913 & 0.018 & 6.777 & $\begin{array}{l}1.636- \\
28.063\end{array}$ \\
$\begin{array}{l}\text { The existence } \\
\text { of mix garden }\end{array}$ & 2.153 & 0.004 & 8.614 & $2.102-$ \\
Constant & $-3,292$ & & & 35.304 \\
\hline Source: primay data & & & \\
\hline
\end{tabular}

Source : primay data

of independent variables to variable dependent. Variabel which were related to the incidence of malariais: the habit of using mosquito nets, use anti mosquito habits, habits are outside the home in the evening. To proceed to the multivariate analysis, all variables that have been performed bivariate analysis and has a value of $\mathrm{p}<0.25$ was selected to serve as a variable.

Based on table, it can be seen that the dominant variable affecting the incidence of malaria is the use of mosquito nets, the use of anti-mosquito, and mixed garden.

Multivariate analysis using logistic regression with method of Backward L / R starting from the selection of the selected variables into a multivariate model until the final stage, it is found is the incidence of malaria risk factors: The use of mosquito nets, the use of anti-mosquito, and the existence of mixed garden. The most dominant risk factors that may contribute to the incidence of malaria is the presence of mixed garden, with $\mathrm{p}=0.004, \mathrm{CI}(95 \%)=2.102$ to 35.304 .

The number of malaria cases in the city of Padang from January to June 2012 as many as 89 cases. Here's a map of the distribution of malaria cases by district in the city of Padang. Decision point location coordinates of malaria cases is done with a GPS (Global Positioning System), thus indicating the location of the distribution of cases in the region.

The map illustrates the distribution of malaria incidence is found in almost all districts in the city of Padang. Most cases are in the District of Koto Tangah, and then District of Kuranji, and District Nanggalo. Grouping cases as shown in the map contained in some locations, such as in Lubuk Buaya, Nanggalo and Lubuk Minturun.

Based on the coordinates of the location of residence malaria, then obtained a map of the distribution of cases shows that the incidence of malaria spread in almost all districts in

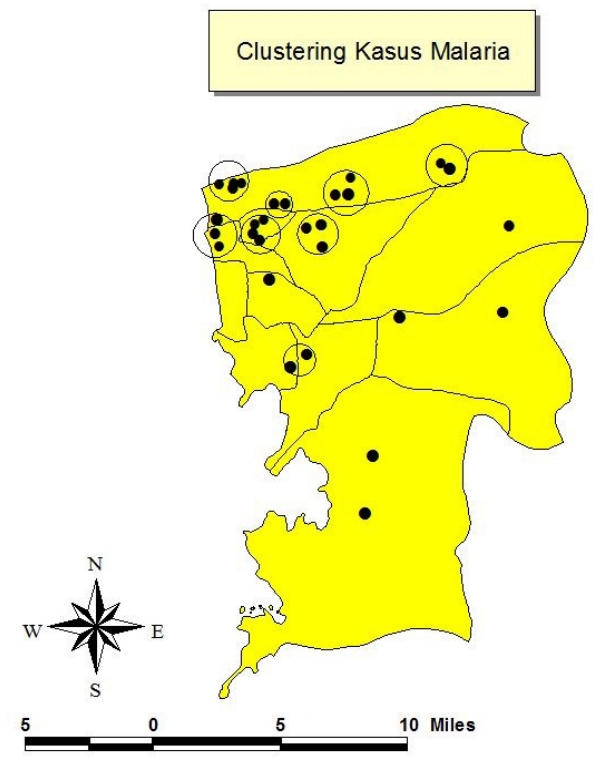

Figure 1. Clustering of malaria cases in the city of Padang

Source : primary data 
the city of Padang.

On the map can be seen the number of cases found in the District of Koto Tangah, followed by the District of Kuranji, and the District Nanggalo. The location is as much as $58.6 \%$ of malaria cases are around swamps, and 65.5\% are mixed around the garden. The presence of swamps and mixed garden in your neighborhood is one of the cases of environmental factors that support the growth of Anopheles mosquitoes that also influence the spread of malaria (Nurbayanti, 2013; Pubianti, 2009).

Based on observations, in addition swamps occur naturally, in some locations found swamps that formed as a result of the environmental impact of human development activities. The existence of these swamps as in Sub Lubuk Buaya, Air Pacah, and Kuranji generally be around the location of housing development and office buildings, in the vici nity of the former excavation found a building material, which is and then filled with water (Shinto, 2014; Sukowati, 2012; Thallane, 2013). Such circumstances could potentially provide breeding sites (breeding place) Anopheles mosquitoes, thus also affect the risk of malaria transmission (Al Tair, 2008; Rosmini, 2013).

The existence of a piece of land that is overgrown with various plants around the location of residence also has the potential to provide resting and breeding places for Anopheles mosquitoes (Edinal, 2006). In general, in most locations residence malaria patients also contained mixed garden, such as in the area of the District of Koto Tangah: Dadok, Tunggul Hitam, Lubuk Buaya, and Lubuk Minturun and District Kuranji, and District of Nanggalo.

The existence of flowing rivers in several districts in the city of Padang also affect the distribution pattern of malaria incidence. As seen in the map, there are cases of malaria are mostly located in the region through which the river flows (Suwito, 2010, Suhardiono, 2005). This is probably related to the habits of the local population who move around the river. The existence of people who like sitting habits, fishing on the banks of the river at night, and there were gathered and spent the night in the stalls located along the river.

\section{Conclusions}

Habits of using mosquito nets and mosquito repellent less common in the cases than controls in Padang and habits out of the house at night is common in the cases than controls in Padang. Swamp and mixed garden is mostly found around the residence of cases.

There is a significant association between the use of customs netting with malaria incidence in the city of Padang. People who do not usually wear a mosquito nett the night when sleep has 4.480 times greater risk than people taking kelambu. The significant association between the use of anti-mosquito customs with the incidence of malaria in the city of Padang. People who do not usually use mosquito repellent has 4,222 times greater risk than people who use anti-mosquito. There is a significant association between customs going out at night with the incidence of malaria. People who usually leave the house at night home has 4,107 times greater risk compared with people who do not usually leave the house at night. There is a significant association between the presence of mixed garden with malaria incidence. People who live around mixed garden has 5.971 times greater risk compared with people who do not reside in the surrounding swamps. There was no significant association between the presence of swamps with malaria incidence.

The dominant risk factors associated with the incidence of malaria such as: the use of mosquito nets, mosquito repellent usage habits and the presence of mixed garden around the residence. Distribution of malaria incidence in the city of Padang spread in almost all districts. Districts that have the highest number of cases followed by the District of Koto Tangah, Kuranji, and District of Nanggalo. There is some clustering (grouping) of malaria cases in some regions. Residence cases are mostly located around swamps and mixed garden. The flow of the river that passes through several districts may influence the distribution pattern of malaria incidence.

\section{References}

Al-Taiar A, et al. 2008. Who develops severe malaria? impact of access to healthcare, 
socio-economic and environmental factors on children in Yemen: a case-control study. Tropical Medicine and International Health, 13 (6): 762-70.

Babba, Ikrayama. 2008. Faktor-faktor Risiko yang Mempengaruhi Kejadian Malaria (Studi Kasus di Wilayah Kerja Puskesmas Hamadi Kota Jayapura). Bina Sanitasi, 1 (1) : 37 - 46.

Ernst KC, Linblode KA, Koech D, Sumba PO, Kuwuor DO, John CC, et al. Environmental, socio-demographic and behavioural determinants of malaria risk in the western Kenyan highlands: a case-control study.Tropical Medicine and International Health. 14 (10): 1258-65.

Erdinal, Dewi Susanna dan Ririn Arminsih. 2006. Faktor-Faktor yang Berhubungandengan Kejadian Malaria di Kecamatan Kampar Kiri Tengah Kabupaten Kampar. Makara Kesehatan. $2: 64-70$.

Friaraiyatini, Soedjajadi K., Ririh Y. 2006. Pengaruh Lingkungan dan Perilaku Masyarakat Terhadap Kejadian Malaria di Kab. Barito Selatan Propinsi Kalimantan Tengah. Surabaya: Universitas Airlangga. 2 (2):121 - 128.

Hakim, Lukman. Sistem Kewaspadaan Dini Kejadian Luar Biasa Malaria Berdasarkan Curah Hujan Kepadatan Vektor dan Kesakitan Malaria di Kabupaten Sukabumi. Media Litbang Kesehatan ; 2007

Handayani L, Pebrorizal, Soeyoko. 2008. Faktor Risiko Penularan Malaria Vivak. Berita Kedokteran Masyarakat, 24 (1) : 38-43.

Kritsiriwuthinan K, Ngrenngarmlert W. 2011. Asymptomatic malaria infections among foreign migrant workers in Thailand. Asian Pacific Journal of Tropical Medicine. 2011, 4 (7): 560-3

Masrizal, Nurdin E, Faktor-faktor yang Brhubungan dengan Kejadian Malaria di Wilayah Tambang emas Kecamatan IV Nagari Kabupaten Sijunjung. Jurnal Kesehatan Masyarakat 6 (2)

Masrizal, Bambang, Hubungan Unsur Iklim Dengan Kejadian Penyakit Deman Berdarah Dengue di Kota Pekan Baru tahun 1998-2008. Jurnal
Kesehatan Masyarakat, 4 (2).

Masrizal. Sistem Informasi Geografis dalam Kesehatan Masyarakat berbasis Arcview dan Healtmapper. Jurnal Kesehatan Masyarakat, 5 (2)

Mardiana, Fibrianto Dwi. 2009. Hubungan Karakteristik Lingkungan luar rumah dengan kejadian malaria.2009.Jurnal Kesehatan Masyarakat, 5 (1) :11-16.

Rubianti, I. Wibowo, A, T. Solikhah. 2009. Faktorfaktor Risiko Malaria di Wilayah Kerja Puskesmas Paruga Kota Bima Nusa Tenggara Barat. Jurnal KESMAS, 3 (3) : 162-232.

Rosmini, dkk. 2013. Jenis-Jenis Habitat Nyamuk Anopheles Spp. Di Kecamatan Labuan dan Kecamatan Sindue Kabupaten Donggala Sulawesi Tengah. Jurnal Vektor Penyakit. 2013, 7 (1): 1-8.

Suwito, et al. (2010). Hubungan Iklim, Kepadatan Nyamuk Anopheles dan Kejadian PenyakitMalaria. Jurnal Entomologi Indonesia, 7 (1), $42-53$

Suhardiono. 2005. Faktor-Faktor yang Berhubungan dengan Insiden Penyakit Malaria di Kelurahan Teluk Dalam Kecamatan Teluk Dalam Kabupaten Nias Selatan. Jurnal Mutiara Kese hatan Indonesia, $2: 22-34$

Sarumpaet SM, Richard T. 2007. Faktor risiko kejadian Malaria di Kawasan Ekosistem Leuser Kabupaten Karo Provinsi Sumatera Utara. Info Kesehatan Masyarakat, 11 (1) : 55-63.

Santi, M, Hakim, L. 2011. Hubungan Faktor Penularan dengan Kejadian Malaria pada Pekerja Migrasi yang Berasal dari Kecamatan Lengkong Kabupaten Sukabumi. Aspirator Vol. 3 (2) : 89-99

Shinta, Sukowati, S, Fauziah. 2008. A. Bionomik Vektor Malaria Nyamuk Anopheles Sundaicus dan Anopheles Letifer di Kecamatan Belakang Padang Batam Kepulauan Riau. Buletin Penelitian Kesehatan, 40 (1) : 11-16

Sukowati, Supratman, Shinta, 2009, Habitat Perkembangbiakan dan Aktivitas Menggigit Nyamuk Anopheles Sundaicus dan Anopheles Subpictus di Purworejo Jawa Tengah. Jurnal Ekologi Kesehatan, 8 (1): 915-925 